Research Article

\title{
A cross sectional study on refractive error among school children aged 6 to 17 years in Chennai, India
}

\author{
Prabha $\mathbf{V}^{1}$, Meriton Stanly $\mathbf{A}^{2}$
}

\begin{abstract}
${ }^{1}$ Department of Physiology, Chamarajanagar Institute of Medical Sciences, Chamarajanagar, Karnataka, India
${ }^{2}$ Department of Community Medicine, Sri Ramachandra Medical College, Porur, Chennai, Tamil Nadu, India
\end{abstract}

Received: 17 October 2015

Accepted: 06 November 2015

\section{*Correspondence:}

Dr. Prabha V,

E-mail: prabhavsetty@gmail.com

Copyright: (c) the author(s), publisher and licensee Medip Academy. This is an open-access article distributed under the terms of the Creative Commons Attribution Non-Commercial License, which permits unrestricted non-commercial use, distribution, and reproduction in any medium, provided the original work is properly cited.

\section{ABSTRACT}

Background: Blindness due to refractive error is a substantial public health problem in many parts of the world. Refractive error would become the second largest cause of treatable blindness after cataract. Refractive error is the most common and avoidable causes of visual impairment. Screening programs need to be implemented to detect individuals suffering from refractive error. Early diagnosis and treatment is the simple and most effective measure to prevent refractive error blindness. The current study was designed to estimate the Prevalence of refractive error among school children.

Methods: This cross sectional study was conducted among 1720 school children of 6- 17 years age group in Chennai. The sample size was estimated by the prevalence of refractive error as $20 \%$, alpha error $5 \%$ and relative precision $10 \%$ of refractive error. School children were screened for defective vision with the help of Snellen's chart.

Results: Total of 1720 children was examined; $49.7 \%$ were boys and $50.3 \%$ were girls. The overall Prevalence of refractive error was $20.9 \%$ and the $95 \%$ Confidence interval was found to be $19.9 \%$ to $20.9 \%$. The Prevalence of refractive error among boys was $10.8 \%$ and in girls was $10.1 \%$. The difference in refractive error among male and female children was small and the difference was found to be statistically insignificant $(\mathrm{p}>0.05)$.

Conclusions: Refractive error is the most common and avoidable causes of visual impairment. Uncorrected refractive error can affect their learning. So, early detection and intervention can improve child's potential tremendously during the formative years.

Keywords: Refractive error, School health, Prevalence

\section{INTRODUCTION}

Blindness due to refractive error is a substantial public health problem in many parts of the world. Refractive error is one of the most common causes of visual impairment. ${ }^{1-3}$ Refractive error as a cause of blindness has been recognized recently. Large numbers of people are blind in different parts of the world due to high refractive errors because they are not using appropriate refractive correction. However, in many parts of the world refractive error would become the second largest cause of treatable blindness after cataract if blindness were defined on the basis of presenting distance visual acuity. ${ }^{4-6}$ Uncorrected refractive error is an avoidable cause of visual impairment. Screening programs need to be implemented to detect individuals suffering from refractive error. VISION 2020- The Right to Sight, initiative to eliminate avoidable blindness has given high priority to correction of refractive error and has placed it within the category of "childhood blindness". " Vision defects due to myopia typically appear during school years. It is the commonest refractive error in school going children and its timely and proper correction saves permanent disability. 


\section{METHODS}

The present cross sectional study was carried out among school children aged 6-17 years in Chennai. The sample size was estimated by the prevalence of refractive error as $20 \%$, alpha error $5 \%$ and relative precision $10 \%$ of refractive error. The required sample size for the study was 1536. 1720 school children were included in the present study. The study was approved by Institutional Ethical Committee. After getting permission from school principal and also consent from the parents the children were screened for refractive errors. The subjects were selected by a detailed history \& thorough physical examination. With the help of an experienced Optometrist, screening was done under the supervision of the investigator and class teachers. The Optometrist examined all the children. The number of students who were found to be having vision problems was carefully noted by the investigator. The details regarding residential area and other information were also collected from students with the help of class teachers. The investigators obtained a detailed history about present and past ocular disorders, history of medical or surgical treatment and a family history of refractive error in the siblings. The distant vision of a child was tested using Snellen's chart at 6 meters. If vision was $<6 / 12$ in either eye, the child was declared to have defective vision. ${ }^{8}$ Children identified with ocular problems that needed examination by an ophthalmologist were referred. Data entry and analysis were done using SPSS -15.0 for windows software. Prevalence of refractive errors and 95\% confidence interval were calculated. Percentage and $\mathrm{p}$ value was calculated.

\section{RESULTS}

Table 1: Distribution of school children by age and sex.

\begin{tabular}{|lllllll|}
\hline $\begin{array}{l}\text { Age } \\
\text { in } \\
\text { years }\end{array}$ & $\mathrm{n}$ & $\%$ & $\mathrm{n}$ & $\%$ & $\mathrm{n}$ & $\%$ \\
\hline $6-8$ & 222 & 12.9 & 230 & 13.4 & 452 & 26.3 \\
\hline $9-11$ & 217 & 12.6 & 232 & 13.5 & 449 & 26.1 \\
\hline $12-14$ & 226 & 13.1 & 213 & 12.4 & 439 & 25.5 \\
\hline $15-17$ & 189 & 11.0 & 191 & 11.1 & 380 & 22.1 \\
\hline Total & 854 & 49.7 & 866 & 50.3 & 1720 & 100 \\
\hline
\end{tabular}

The study population comprised of 1720 children, out of which $49.7 \%$ were boys and $50.3 \%$ were girls. Among the selected children most of the children were in the age group 6-8 years followed by 9-11 years. The least proportion of children was in the age group 15- 17 years. Among males, most of the children were in the group 1214years followed by 6-8 years. Among the female children, the highest proportion of children was in the age group 9-11years. The least proportion of female children was in the age group 15-17 years. Age and sex distribution is tabulated in Table 1. About $360(20.9 \%)$ children had difficulty in reading the chart from a distance of 6 meters. The Prevalence of Refractive error in our study was $20.9 \%$ and the $95 \%$ confidence interval was found to be $19.9 \%$ to $21.9 \%$. The $95 \%$ confidence interval was quite narrow and it proves that the present study had sufficient sample size. The results were shown in the Table 2. The Prevalence of refractive error in boys was $10.8 \%$ and in girls was $10.1 \%$. The difference in refractive error in boys \& girls was narrow and found to be statistically insignificant $(\mathrm{p}>0.05)$. The prevalence of refractive error was high in the age group 12-14 years followed by 9-11 years. The prevalence of refractive error in different age group and sex is given in Table 3 .

Table 2: Prevalence of refractive error.

\begin{tabular}{|lll|}
\hline Refractive error & Frequency & Percentage \\
\hline No & 1360 & 79.1 \\
\hline Yes & 360 & 20.9 \\
\hline Total & 1720 & 100.00 \\
\hline
\end{tabular}

Table 3: Prevalence of refractive error.

\begin{tabular}{|lllll|}
\hline $\begin{array}{l}\text { Age in } \\
\text { Years }\end{array}$ & \multicolumn{2}{l}{$\begin{array}{l}\text { Refractive Error } \\
\text { in males }\end{array}$} & $\begin{array}{l}\text { Refractive error } \\
\text { in Females }\end{array}$ \\
\hline $6-8$ & 36 & No & Yes & No \\
\hline $9-11$ & 54 & 166 & 33 & 197 \\
\hline $12-14$ & 61 & 165 & 51 & 181 \\
\hline $15-17$ & 34 & 155 & 32 & 154 \\
\hline Total & 185 & 669 & 175 & 691 \\
\hline
\end{tabular}

\section{DISCUSSION}

Refractive error can hinder education, personality development, and career opportunities, in addition to causing an economic burden on society. Refractive error in school children can be detected through routine vision screening. It is necessary in developing countries because a large majority of the population does not have access to reasonable quality eye care services. Screening school children is arguably the second largest National program for control of blindness in India after cataract surgery. In our study a large sample of 1720 children were screened and had the prevalence of refractive error among the school children was $20.9 \%$. A low prevalence of refractive errors of $2 \%$ has been reported from Eastern India by Datta et al, among primary school children of 513 years. ${ }^{9}$ Internationally prevalence of refractive errors among children of age 5-15 years from Africa and Finland ranges from $(2.7-5.8 \%) .{ }^{10}$ Prevalence of visual impairment in children varies from as low as $2.72 \%$ in South Africa to as high as $15.8 \%$ in Chile. ${ }^{11-12}$ Less than $1 \%$ prevalence of refractive errors was reported in primary school children in rural Tanzania, $1 \%$ in Katmandu, $14.8 \%$ in Malaysia. ${ }^{13-15}$

Recent data suggest that there has been an increase in the prevalence of refractive errors in some parts of the world 
over the past few decades. ${ }^{16-18}$ The reasons may be due to the use of electronic gadgets and lack of outdoor activities by school children. This trend could have resulted in a higher prevalence of high myopia which, if not adequately corrected, could result in an increase in the number of avoidable blindness due to refractive error.

\section{CONCLUSION}

Most of the children were unaware of their problem and prevalence of refractive error was high in our study. The existing school health services should be strengthened and implemented effectively to prevent refractive errors and to achieve the goal of Vision 2020. Uncorrected refractive error may have impact to a larger extent on their learning. Refractive errors among school children can hinder education, personality development, and career opportunities, in addition to causing an economic burden on society. Timely detection and intervention can improve child's potential tremendously during the formative years.

\section{ACKNOWLEDGEMENTS}

We would like to express our gratitude to the participants involved in the study.

Funding: No funding sources

Conflict of interest: None declared

Ethical approval: The study was approved by the Institutional Ethics Committee

\section{REFERENCES}

1. Attebo K, Mitchell P, Smith W. Visual acuity and the causes of visual loss in Australia: the Blue Mountain Eye Study. Ophthalmology. 1996;103:357-64.

2. Taylor HR. Visual impairment in Australia: distance visual acuity, near vision, and visual field findings of the Melbourne Visual Impairment Project. American Journal of Ophthalmology. 1997;123:328-37.

3. Dandona L. Burden of moderate visual impairment in an urban population in southern India. Ophthalmology. 1999;106:497-504.

4. Memon MS. Prevalence and causes of blindness in Pakistan. Journal of Pakistan Medical Association. 1992;42:196-8.

5. Mansour AM. National survey of blindness and low vision in Lebanon. British Journal of Ophthalmology. 1997;81:905-6.
6. Zerihun N, Mabey D. Blindness and low vision in Jimma Zone, Ethiopia: results of a population-based survey. Ophthalmic Epidemiology. 1997;4:19-26.

7. Resnikoff S, Pascolini D, Mariotti SP, Pokharel GP. Global magnitude of visual impairment caused by uncorrected refractive errors in 2004. Bull World Health Organ. 2008;86:63-70.

8. World Health Organization. Elimination of avoidable visual disability due to refractive error Report of an informal planning meeting. WHO/PBL/00.79.

9. Laatikainen L, Erkkila H. Refractive errors and other ocular findings in school children. Acta Ophthalmol. 1980;58:129-36.

10. Pratap VB, Lal HB. Pattern of pediatric ocular problem in North India. Indian $\mathbf{J}$ Ophthalmol. 1989;37:171-2.

11. Maul E, Barroso S. Munoz SR. Sperduto RD. Ellwein LB. Refractive error study in children: results from La Florida. Chile. Am J Opthalmol. 2000;129:445-54.

12. Naidoo KS, Raghunandan A, Mashige KP, Govender P, Holdebn BA, Pokharel GP, et al. Refractive error and visual impairment in African children in South Africa. Invest Opthalmol Vis Sci. 2003;44:3764-70.

13. Wedner SH, Ross DA, Balira R, Kaji L, Foster A. Prevalence of eye diseases in primary school children in a rural area of Tanzania. $\mathrm{Br} \mathrm{J}$ Opthalmom. 2000;84:1291-7.

14. Nepal BP, Koirala S, Adhikary S. Ocular Morbidity in school children in kathmandu. Br J Ophthalmol. 2002;87:531-4.

15. Goh PP, Abqariyah Y, Pokharel GP, Ellwein LB. Refractive error and visual impairment in schoolage children in Gombak District. Malaysia. Ophthalmology. 2005; 112:378-85.

16. Goh WS, Lam CS. Changes in refractive trends and optical components of Hong Kong Chinese aged 1939 years. Ophthalmic and Physiological Optics. 1994;14:378-82.

17. Wensor M, McCarty CA, Taylor HR. Prevalence and risk factors of myopia in Victoria, Australia. Archives of Ophthalmology. 1999;117:658-63.

18. Attebo K, Ivers RQ, Mitchell P. Refractive errors in an older population: the Blue Mountains Eye Study. Ophthalmology. 1999;106:1066-72.

Cite this article as: Prabha V, Stanly AM. A cross sectional study on refractive error among school children aged 6 to 17 years in Chennai, India. Int J Community Med Public Health 2016;3:71-3. 